\title{
SUSPEITA DE INFECÇÃO PELO NOVO CORONAVÍRUS EM LACTENTE VENEZUELANA COM SÍNDROME RESPIRATÓRIA AGUDA GRAVE
}

DOI: $10.47224 /$ rm.v5i10.145

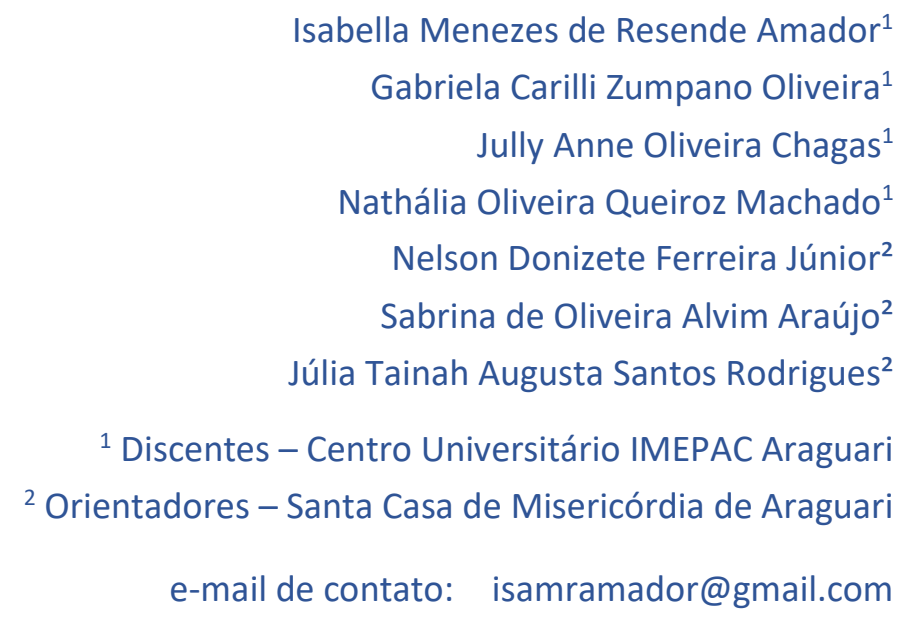

Lactente, sexo feminino, 1 ano e 1 mês, venezuelana, imigrou com os pais para o Brasil em fevereiro de 2020, procedente de Roraima e, atualmente, reside em Araguari, Minas Gerais. O idioma espanhol dificultou a consulta, mas segundo os pais, em Roraima, a paciente adquiriu pneumonia e ficou internada, por sete dias, em terapia intravenosa desconhecida com resolução do quadro. Em Araguari, apresentou tosse e foi medicada pela mãe; dois dias depois, sem melhora, foi levada ao pronto atendimento com tosse, rinorreia, febre, sem sinais de gravidade, após isso, solicitou-se PCR de swab nasofaríngeo, para suspeita de COVID-19, e foi liberada para tratamento e isolamento domiciliar enquanto aguardavam o resultado. Após quatro dias, com piora do quadro, a paciente retornou ao pronto atendimento e foi encaminhada para um hospital secundário, com dispneia e dessaturação, e mantida em isolamento privativo até resultado da PCR. Além disso, possui antecedentes de broncoespasmo, obstipação intestinal, nunca fez suplementação de ferro e o calendário de imunização apresentava atraso em relação às seguintes vacinas:

- Pneumocócica conjugada 10-valente;

- Meningocócica C conjugada;

- Tetraviral (sarampo, caxumba, rubéola e varicela);

- Hepatite A;

- Influenza;

- Rotavírus humano. 
No momento da admissão: regular estado geral, hipocorada $(2+/ 4+)$, dispneica empregando musculatura acessória (retração de fúrcula e tiragem intercostal); frequência cardíaca 162 bpm, frequência respiratória 54 irpm, saturação de oxigênio $88 \%$ em ar ambiente, temperatura axilar 36,8ㄷ; murmúrio vesicular diminuído à ausculta pulmonar direita; sem outras alterações. Solicitou-se hemograma completo, íons, função renal, proteína C-reativa e radiografia de tórax (Figura 1), o qual evidenciou consolidação em terço médio e superior direito e em terço inferior esquerdo.

Figura 1 - Radiografia de tórax da paciente.

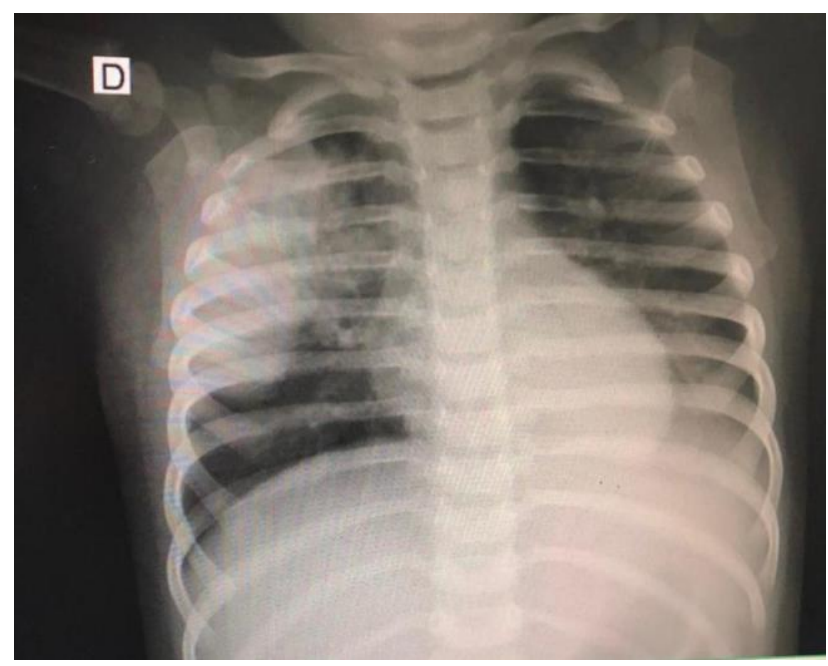

Fonte: os autores.

Os exames laboratoriais identificaram anemia microcítica, hipocrômica com anisocitose; leucocitose, neutrófilos com granulações tóxicas; proteína C-reativa elevada $(93 \mathrm{mg} / \mathrm{L})$; sem demais alterações.

Com resultado da PCR de swab nasofaríngeo negativo para COVID-19, a paciente foi encaminhada do isolamento para a enfermaria pediátrica.

Administrou-se broncodilatador para resgate e manutenção, oxigenoterapia nasal, antibioticoterapia, antiviral para Influenza A e corticoterapia. Ademais, a paciente também precisou de oxigenoterapia com $\mathrm{O} 2$ sob cateter nasal por quatro dias, com desmame gradual, ainda, realizou-se transfusão de hemoconcentrado devido à intensa anemia associada à necessidade de oxigênio.

Houve resolução da febre em 72 horas de antibioticoterapia e melhora da taquidispneia, portanto, a paciente recebeu alta após 10 dias de internação em uso de amoxicilina-clavulanato $90 \mathrm{mg} / \mathrm{kg} / \mathrm{dia}$ por mais 4 dias. 
1. Aleitamento materno com alimentação complementar desconhecida.

2. Paciente 1 ano e 1 mês (não sabe determinar de forma precisa os sintomas).

3. Pais imigrantes.

4. Idioma espanhol.

5. Baixa renda familiar.

6. Ausência de acompanhamento em unidade básica de saúde (UBS).

7. Pandemia em decorrência da COVID-19.

1. Síndrome respiratória aguda grave.

2. COVID-19?

3. Pneumonia bacteriana muito grave?

4. Gripe A?

5. Anemia moderada (Ferropriva?).

6. Obstipação intestinal crônica.

7. Atraso vacinal.

8. Ausência de suplementação de ferro.

Lago et al. (2020) relatam que o Brasil e o mundo passam pela pandemia por infecção do novo coronavírus e, mesmo que as taxas de complicação e mortalidade entre as crianças sejam baixas, elas são algumas das principais transmissoras do vírus, portanto, é de suma importância que as equipes de urgência e emergência pediátrica estejam preparadas para o atendimento destes pacientes.

Ademais, a procedência da paciente também tem relevância, pois, segundo Arruda-Barbosa et al. (2020), a migração de venezuelanos para a Roraima acontece, principalmente, por busca de atendimento em saúde, localidade onde a paciente ficou internada por sete dias com diagnóstico de pneumonia (SIC). Esta demanda de imigração ocasionou sobrecarga do sistema público de saúde, tamanho impacto orçamentário gerou decreto de estado de emergência com atendimento de baixa qualidade. Os autores ainda relatam que estes imigrantes estão entre os $20 \%$ mais pobres do mundo, fato que agrava o índice de mortalidade materno-infantil. Por fim, o idioma também é considerado um entrave para os profissionais, causando limitação na assistência à saúde. 
Apesar do obstáculo representado pela diferença de idiomas, a história clínica da paciente, como descrita anteriormente, relata que ela é natural da Venezuela, chegou ao Brasil com os pais, em fevereiro de 2020, e esteve em Roraima, região em que foi internada por pneumonia durante sete dias e, em seguida, evoluiu para cura. Após isso, mudou-se para Araguari - MG, onde voltou a apresentar sintomas respiratórios, foi medicada pela mãe e, sem melhora, foi levada ao pronto atendimento com sinais de infecção de via aérea superior. Na admissão, realizou PCR de swab nasofaríngeo para COVID-19 e H1N1 e recebeu alta com orientação de tratamento e isolamento domiciliar. Após quatro dias, retornou ao pronto atendimento com piora dos sintomas, foi encaminhada ao hospital secundário e, ainda sem resultado de swab, teve hipóteses diagnósticas de síndrome respiratória aguda grave, pneumonia muito grave, crise de broncoespasmo grave, infecção por H1N1 e COVID-19.

Sem a determinação do agente etiológico do quadro pulmonar e de acordo com as novas recomendações devido à pandemia por COVID-19, enquanto aguardava o resultado da pesquisa viral, a paciente foi isolada em quarto privativo com banheiro no referido hospital, onde há equipe de enfermagem exclusiva para pacientes com quadros suspeitos e confirmados do novo coronavírus. O resultado da pesquisa de PCR em swab resultou negativo para coronavírus e H1N1, logo, a paciente pôde ser retirada do isolamento e encaminhada ao setor pediátrico.

Neste cenário, vale ressaltar que a paciente em questão possuía um calendário vacinal desatualizado, com falhas em vacinas importantes, como a vacina pneumocócica conjugada 10-valente que, segundo Silva et al. (2016), é importante, visto que reduz as chances das crianças abaixo dos 2 anos e vacinadas contraírem doenças pneumocócicas, como as meningites e as pneumonias adquiridas na comunidade, além de ser importante fator para redução das internações, desnutrição, mortalidade e absenteísmo no trabalho dos pais, bem como redução dos custos para a saúde. Dessa maneira, foi referida à atenção primária mais próxima de sua residência para atualização de suas vacinas.

O tratamento foi feito com Salbutamol Spray com espaçador e máscara por 8 dias (inicialmente, foi realizado resgate, em seguida, espaçado de $1 / 1$ hora e, posteriormente, com intervalos maiores em dias subsequentes conforme tolerância da criança); oxigenoterapia $2 \mathrm{~L} / \mathrm{min}$ sob cateter nasal; antibioticoterapia com Ceftriaxona $90 \mathrm{mg} / \mathrm{kg} / \mathrm{dia}$, Oxacilina $180 \mathrm{mg} / \mathrm{kg} / \mathrm{dia}$ via endovenosa por 7 dias e Amoxicilina-Clavulanato $90 \mathrm{mg} / \mathrm{kg} /$ dia via oral por mais 4 dias; Oseltamivir via oral de 12/12 horas por 5 dias e Prednisolona $2 \mathrm{mg} / \mathrm{kg} / \mathrm{dia}$ via oral por 5 dias.

Conjuntamente, os pais referiram que a paciente possui quadro de obstipação intestinal desde o primeiro mês de vida e, a partir disso, fazem uso de supositório em dias alternados. Desta forma, os pais foram orientados acerca da maneira que deve funcionar o trato intestinal da lactente e, para resolução do quadro, foi realizado um fleet enema associado à dieta laxativa. 
Em decorrência da anemia associada à dependência de oxigênio, realizou-se transfusão de concentrado de hemácias de $10 \mathrm{ml} / \mathrm{kg}$. A paciente nunca fez suplementação de ferro e, como no Brasil, desde 2005, o Programa Nacional de Suplementação de Ferro preconiza o uso de ferro profilático nas crianças, os pais foram orientados sobre a inserção de alimentos com ferro nas refeições da criança, além de uma dose terapêutica de $5 \mathrm{mg} / \mathrm{kg} /$ dia de ferro elementar por, no mínimo, 8 semanas. Ademais, foi referida também para a atenção primária mais próxima de sua residência, seguindo as orientações de suplementação continuada para repor os estoques de ferro.

Portanto, a paciente evoluiu com resolução de febre em 72 horas de antibioticoterapia e melhora gradual de taquidispneia. Recebeu alta após 10 dias de internação, permanecendo com o uso de AmoxicilinaClavulanato $90 \mathrm{mg} / \mathrm{kg} / \mathrm{dia}$ por mais 4 dias.

\section{REFERÊNCIAS}

ARRUDA-BARBOSA, Loeste de; SALES, Alberone Ferreira Gondim; TORRES, Milena Ellen Mineiro. Impacto da migração venezuelana na rotina de um hospital de referência em Roraima, Brasil. Interface-Comunicação, Saúde, Educação, v. 24, p. e190807, 2020.

DA SILVA, Sandra Rodrigues et al. Impacto da vacina antipneumocócica 10-valente na redução de hospitalização por pneumonia adquirida na comunidade em crianças. Revista Paulista de Pediatria, v. 34, n. 4, p. 418-424, 2016.

LAGO, P. et al. Recomendações para Atendimentos de Casos Suspeitos de COVID-19 em Emergências Pediátricas Associação Brasileira de Medicina de Emergência (ABRAMEDE). 2020.

SOCIEDADE BRASILEIRA DE PEDIATRIA. Consenso sobre anemia ferropriva: mais que uma doença, uma urgência médica! Departamentos de Nutrologia e Hematologia-Hemoterapia. 2018. 